\title{
THE JOURNAL OF BRITISH STUDIES
}

\author{
UNIVERSITY OF ILLINOIS \\ AT CHICAGO \\ CHICAGO, ILLINOIS
}

The Journal of British Studies, founded in 1961, is published at the University of Illinois at Chicago under the auspices of the North American Conference on British Studies. It was the result of the imaginative generosity of a Trinity College alumnus, Frederick $E$. Hasler (Hon. LL.D. 1957) who contributed funds to the College for the specific purpose of establishing a learned periodical in the field of British history. Several Trinity alumni subsequently contributed to the fund. The University of Illinois at Chicago now supports the publication of the Journal.

The North American Conference on British Studies is a scholarly society affiliated with the American Historical Association and open to anyone in the United States and Canada interested in British civilization in its several aspects: historical, archaeological, literary, artistic, political, and sociological. Its North American constituency comprises about 800 members drawn from the fifty states and the ten provinces. Affiliated with the parent organization are seven regional conferences (New England, Middle Atlantic, South, Midwest, Western, Pacific Coast, and Northwest), each having its own officers, programs, and other activities and with a combined membership of more than 2,000. The Conference convenes at least once a year in the autumn, usually in joint session with one of its regional affiliates. It seeks to encourage the serious study of British history, literature, politics, as well as allied subjects, and among the general reading public through meetings, book prizes, association with likeminded organizations in North America and Britain, and through its publications program.

The Conference sponsors a wide variety of publications. The Journal of British studies is published at the University of Illinois at Chicago. Another journal, Albion, issued four times a year at Appalachian State University, Boone, North Carolina, and sent to all members of the parent organization, includes articles, the proceedings of the Conference at its regional and national meetings, and book reviews. The Conference also sponsors several book series, including Current Research in British Studies, a periodic survey of research in progress, edited and published at Kansas State University, Manhattan; Studies in British History and Culture, a monograph series, edited at Wittenberg University, Springfield, Ohio, and published by Archon Books; and a biographical series, edited at Indiana University at South Bend, and published by Shoestring Press. Another series, on bibliography, is edited at Stanford University and published by Cambridge University Press. The Conference's newsletter, The British Studies Intelligencer, also sent to its members, is 
published at the University of California, Irvine. It contains notices of meetings throughout North America and Britain devoted to British studies, news of appointments, moves, and retirements by those active in the profession, announcements of major new research projects, and notes on current publications and individual research in progress.

Through the award of a number of book prizes, the Conference seeks to encourage publications in the fields of British history, culture, and politics.

The Journal of British Studies appears twice in the academic year, in the Fall and in the Spring. Inquiries about subscriptions should be directed to Bentley B. Gilbert, Editor, The Journal of British Studies, Department of History, University of Illinois at Chicago, Box 4348, Chicago, Illinois 60680.

Manuscripts, not exceeding 8,000 words of text, should be sent also to Professor Bentley B. Gilbert at the same address. Please send two copies and a self-addressed return stamped envelope. 


\section{Endangered Lives}

Public Health in Victorian Britain Anthony S. Wohl

Anthony Wohl offers a detailed examination of the social and physical environment in which the people of Victorian Britain lived, and of the effects of the surroundings-both public and domestic-upon people's health. $\$ 20.00$

\section{Riots and Community Politics in England and Wales, 1790-1810 \\ John Bohstedt}

Using statistical analysis of six hundred riots and carefully drawn comparative case studies, Bohstedt examines and explains why riot was the most widespread and successful form of popular politics of the eighteenth century in England and Wales. $\$ 30.00$

\section{Ideas of the Restoration in English Literature, 1660-1671}

Nicholas Jose

Jose brings together a wide range of responses to the Restoration of Charles IIpanegyrics, satires, pageants, plays, memoirs, histories-by forgotten hacks as well as lauded poets. $\$ 15.00$

\section{The Puritan Moment}

The Coming of Revolution in an English County

\section{William Hunt}

"Hunt's purpose is to present an overall argument about Essex's response to national developments in the period from the 1570 s to 1642 . He has written a well-researched and stimulating book ... his zest and enthusiasm carry the story along."

-Times Literary Supplement Harvard Historical Studies, 102 $\$ 36.00$

\section{Harvard University Press}

Cambridge, MA 02138 


\section{Robert Smythson and the Elizabethan Country House Mark Girouard}

This handsomely illustrated book by the author of Life in the English Country House details a fascinating chapter in the social and architectural history of Elizabethan England.

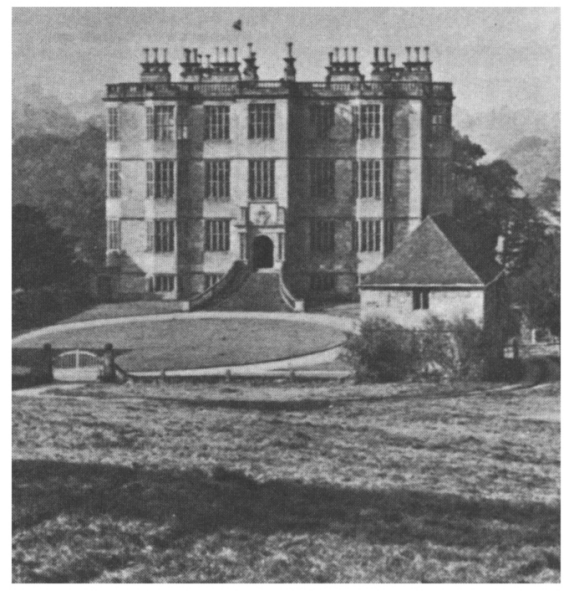

"Valuable to scholars, students, and true fans of the period.... There are impressive pictures, many in color, of great houses, their grounds and interiors, with drawings of details and floor plans." -Edmund Fuller, The Wall St. Journal $200 \mathrm{~b} / \mathrm{w}+$ 16 color illus. $\$ 35.00$

\section{The Image of the Architect}

\section{Andrew Saint}

A lively and wide-ranging discussion of the changing role of the architect in Britain and the United States from 1800 to the present. Saint explores such provocative topics as the portrayal of the architect as "hero" in Ayn Rand's The Fountainbead; the image of the British gentleman architect between the wars; the effect of the Bauhaus on modern architectural theory; and the growth of the business ideal among architects.

"Erudite and highly readable."-Clive Aslet, Country Life 59 illus. $\$ 19.95$

\section{Constable}

The Painter and His Landscape

Michael Rosenthal

The first detailed historical and biographical study of the period in which Constable produced his most famous paintings.

"A fascinating new book... Rosenthal has taken a fresh and intelligent look at many of Constable's works, great and small, and I for one am grateful to him."-John Russell, The New York Times $170 \mathrm{~b} / \mathrm{w}+$ 70 color illus. $\$ 29.95$

\section{Selling Art in Georgian London}

The Rise of Arthur Pond

Louise Lippincott

This lively picture of the London art world during the mid-eighteenth century shows how Arthur Pond's successful career as a dealer and printseller helped to shape the tastes of the English art-buying public and to develop the commercial trade and audiences that would support later generations of British painters. Published for the Paul Mellon Centre for Studies in British Art. $\quad 40$ illus. $\$ \mathbf{\$ 2 7 . 5 0}$

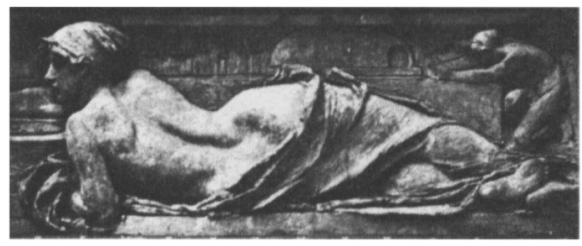

\section{The New Sculpture}

Susan Beattic

In her fascinating study of the British sculptors who joined together in the last decade of the nineteenth century to rede fine the nature of their art and its role in society, Susan Beattie sheds new light on a long-neglected era in British art history. Published for the Paul Mellon Centre for Studies in British Art. $240 \mathrm{~b} / \mathrm{w}+2$ color illus. $\$ 45.00$
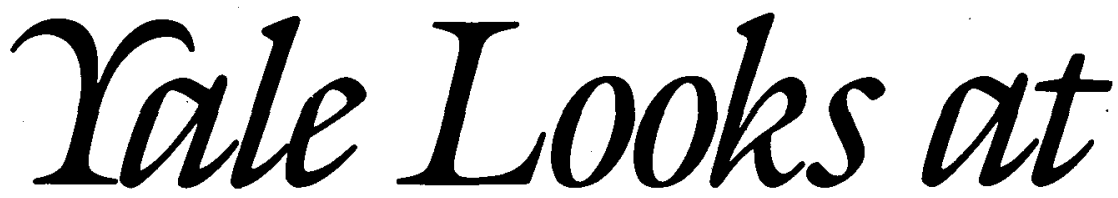


\section{The Cult of the Prince Consort}

Elisabeth Darby and Nicola Smith

Mingling biography with cultural politics and art history, this absorbing book examines the frenzy of commemorative rituals and monuments that followed the death of Queen Victoria's beloved husband. It explores the total range of public and private tributes to Prince Albert as well as the motivation and consequences of this extraordinary phenomenon. 130 illus. $\$ 20.00$

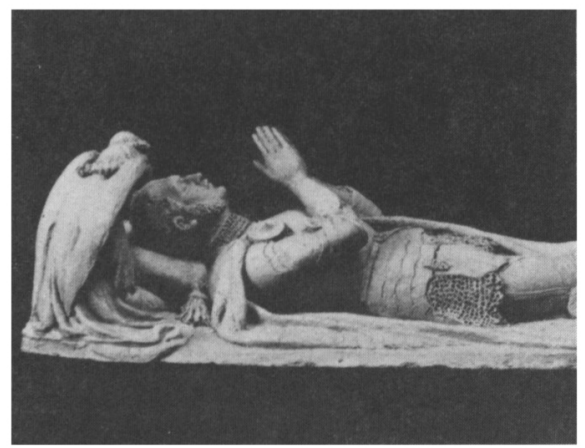

\section{The Yale Edition of Horace Walpole's Correspondence} Volume 43: Additions and Corrections compiled by Edwine M. Martz, with the assistance of Ruth $\mathrm{K}$. McClure and William T. LaMoy $\$ 65.00$

Volumes 44-48: Complete Index compiled by Warren Hunting Smith, with the assistance of Edwine M. Martz, Ruth K. McClure, and William T. LaMoy $\$ 325.00$ the set

\section{The Diary of Joseph Farington}

Volumes XI and XII

edited by Kathryn Cave

These eleventh and twelfth volumes of Farington's famous diaries give his accounts of Academy exhibitions from 1811 to 1813 and discuss the political events of the time. Published for the Paul Mellon Centre for Studies in British Art. $\$ 100.00$

\section{New Paperbounds}

\section{Unbuilt Oxford}

Howard Colvin

A visually spendid and elegantly written exploration of the most interesting of the abortive building projects in the city of Oxford-from the schemes for the Bodleian Library in the sixteenth century to the unexecuted designs of the twentieth century. $190 \mathrm{~b} / \mathrm{w}+8$ color illus. Available in cloth $(\$ 40.00)$ and paper (\$14.95) editions

\section{Indian Summer}

Lutyens, Baker, and Imperial Delbi

Robert Grant Irving

This lively and handsome account of the creation of Imperial Delhi is the winner of the 1983 British Council Prize in the Humanities.

"A rich blend of architectural, political, and social history." - Paul Goldberger, The New York Times Book Review $180 \mathrm{~b} / \mathrm{w}+93$ color illus. $\$ 15.95$

\section{The Yale English Poets \\ Christopher Ricks, General Editor}

"One of the most cheering developments in recent publishing. Each volume provides a newly edited text, with full annotation, a table of dates, a reading-list and indexes, all in a pleasant readable format-and remarkably inexpensive."-Barbara Everett, London Review of Books

\section{Alfred, Lord Tennyson} Idylls of the King edited by J.M. Gray $\$ 7.95$

John Skelton:

The Complete English Poems edited by John Scattergood $\$ 9.95$ Jonathan Swift: The Complete Poems

edited by Pat Rogers $\$ 14.95$

Yale University Press

New Haven and London 


\section{William Pitt the Younger}

\section{The Reluctant Transition}

John Ehrman. This second volume of a definitive threevolume biography centers on the middle years of Pitt's career-from 1789 and the aftermath of the Regency crisis to $\mathbf{1 7 9 6}$ and the end of the first wartime coalition-and shows the brilliant young Prime Minister grappling with one of the most prolonged crises Britain had ever known. Illus. $\$ 39.50$

The first volume in a series: William PItT the Younger: The YeARS OF ACCLAIM (1969). Illus. \$45.00

Order from your bookstore, please

\section{Stanford University Press}

\section{Historians, Puritanism, and the English Revolution}

THE RELIGIOUS FACTOR IN ENGLISH POLITICS BEFORE AND AFTER THE INTERREGNUM

Michael G. Finlayson

This study suggests a way of approaching 17th-century English political history in which continuity, not revolutionary discontinuity, is the paradigm. Finlayson suggests that Puritanism has been too widely attributed to contemporaries and proposes instead that anti-catholicism might more adequately explain successive political crises between 1621 and 1641 , and 1666 and 1688 , and might simultaneously create fewer anomalies. '... an original re-appraisal of some of the most heavily worked-over topics in British history ... fresh, challenging ... offers a reasoned and coherent interpretation of the part played by religious issues in seventeenth-century Britain. (Finlayson) develops and formulates questions and hypotheses which every historian of Stuart Britain will have to take into account.' Professor J.R. Jones, University of East Anglia $\$ 27.50$

\section{UNIVERSITY OF TORONTO PRESS}

33 East Tupper St., Buffalo NY 14203 


\section{An acknowledged leader in the field . . .}

\author{
A HISTORY OF \\ ENGLAND \\ Fourth Edition \\ Lacey Baldwin Smith, \\ Northwestern University \\ General Editor
}

Volume I: The Making of England-55 B.C. to 1399

C. Warren Hollister, University of California, Santa Barbara 1983 Paper 318 pages

Volume II: This Realm of England-1399 to 1688

Lacey Baldwin Smith, Northwestern University 1983 Paper 343 pages
Volume III: The Age of Aristocracy -1688 to 1830

William B. Willcox, Yale University

Walter L. Arnstein, University of Illinois, Urbana-Champaign

1983 Paper 324 pages

Volume IV: Britain Yesterday and Today -1830 to the Present Walter L. Arnstein, University of Illinois, Urbana-Champaign 1983 Paper 462 pages
This comprehensive four-volume survey explores English history from 55 B.C. to the present. Each volume is a complete text, incorporating the most recent scholarship in economic, social, and political history in a clear chronological format. The authors expertly depict the shaping of Britain's history and skillfully draw students into its drama.

For details or sample copies, call us toll free: 800-225-1388 In Massachusetts, call collect: 617-863-1948
Highlights

- 250 new photographs

- More than 50 new maps, plus additional charts and graphs

- More in-depth discussions on social and economic history

- Recent historical interpretations by British and American scholars

- Updated bibliographies

\section{from D. C. Heath}




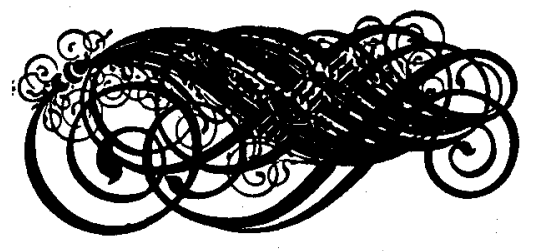

VICTORIAN STUDIES Announces the Forthcoming Essays in Volume 27:

"THE CHILDREN'S FRIEND SOCIETY AT THE CAPE OF GOOD HOPE," by EdNa Bradlow

“A FRIEND TO MAMMON: SPECULATION IN VICTORIAN LITERATURE," by JOHN R. REED

"JOHN CONOLLY: A VICTORIAN PSYCHIATRIC CAREER," by ANDREW SCULL

“THE BIOGRAPHER AND EDWARD VII: SIR SIDNEY LEE AND THE EMBARRASSMENTS OF ROYAL BIOGRAPHY," by Carolyn W. White

"LORD LYTTON AND THE SECOND AFGHAN WAR: A PSYCHOHISTORICAL STUDY," by JohN Lowe DuthIE

"THE POOR LAW REPORTS OF 1909 AND THE SOCIAL THEORY OF THE CHARITY ORGANIZATION SOCIETY," by ANDREW VINCENT

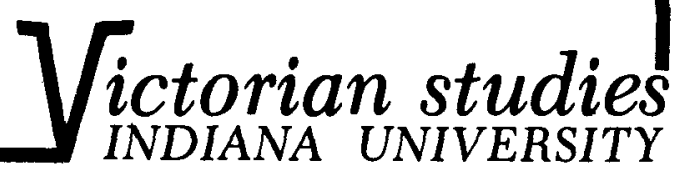


